\title{
TEACHERS' PERCEPTIONS OF THE CONSEQUENCES OF INTERPERSONAL CONFLICT: A CASE STUDY IN THREE PRIMARY SCHOOLS
}

\author{
Gerard Cain, André du Plessis \\ Nelson Mandela Metropolitan University, South Africa \\ E-mail: andre.duplessis@nmmu.ac.za, rcain@mweb.co.za
}

\begin{abstract}
The purpose of this qualitative intrinsic interpretive case study, which formed part of a larger Master in Education Study, is to report on the perceptions of teachers in three primary schools regarding the consequences of conflict among educators. Fifty nine educators, including principals, participated in this study that utilised an open-ended questionnaire, semi-structured interviews and focus-group interviews. The rationale for this study was to ascertain what the perceived consequences of conflict are, in order that these schools as well as the district office of the Department of Basic Education could have a sense of what the perceived consequences are as portrayed by the participants. Hence, participants were able to tell their stories through using text and voice. The findings suggest that the consequences of conflict can be categorised as functional (positive) and dysfunctional (negative) outcomes, each with subsidiary themes. Overall, conflict was experienced as a negative force in general, that is perceived as causing defiant attitudes, intolerance, poor cooperation and teamwork, poor relationships, division of unity, poor morale and work ethic, has a negative impact on wellness, leads to absenteeism and ultimately adversely impact on the learners'learning. On the other hand the positive consequences were improved relationships among staff, greater understanding, improved attitudes, positive change and even personal growth.
\end{abstract} Keywords: Conflict, conflict theories, consequences, dysfunctional conflict, functional conflict

\section{Introduction}

Conflict is not a new phenomenon in society, as it is part and parcel of our being or humanness (Hendel, Fish \& Galon, 2005; Ahuja, 2006), something that we as human beings cannot avoid (Haraway \& Haraway, 2005; Kohlrieser, 2006) as it is evident in all spheres of life (Haraway \& Haraway, 2005). Pondy (1967), a seminal writer on conflict, refers to conflict as something dynamic as it can be latent, overt, felt, manifest and be perceived in various forms and at different levels of intensity. If it is part of our everyday lives, this also implies that there is the potential for conflict in organisations (Ikeda, Veludo-de-Oliveira \& Campomar, 2005), which in turn implies that it will also be present in its various forms as suggested above by Pondy (1967) in our schools, as Ngcobo (2003, p. 187) states “... the very nature of education and schooling generates conflict." Therefore, it is not something that educators should ignore, avoid or deny, but thus something that should rather be dealt with (Du Plessis, Eloff \& Bouwer, 2002). However, every person is different; hence their perceptions of conflict and how it should be dealt with will therefore not be similar, as certain individuals will perceive it as negative or harmful while others again would perceive conflict as positive and beneficial (Guttman, 2009; Rahim, 2011; Samantara, 2004; Stanley \& Algert, 2007). Hence, conflict can be categorised as either being functional or dysfunctional with positive and negative outcomes (Rahim, 2011). 
OF MANAGEMENT

IN THE $21^{\text {st }}$ CENTURY Volume 8,2013

\section{Background and Rationale}

The South African schools system is not immune to conflict, in fact, there seems to be conflict on regular occasions between teacher unions and the Department of Basic Education and among teachers. The two main unions within the South African context are the South African Democratic Teachers' Union (SADTU) and the National Professional Teachers' Association of South Africa (NAPTOSA), the former being the largest union. These tensions and conflict can be attributed to various possible reasons, but probably due to the fact that there are two types of educational 'systems' in South Africa, yet it is the same educational system. This refers to a very small number of top and moderate performing schools in contrast to the large majority of schools which are functioning and performing on a poor or very poor level (Spaull, 2012; Taylor, 2007; 2008). The main reason for these two types of performing schools can be ascribed as a result of colonialism and the apartheid discriminatory policies prior to the 1994 democratic elections (Spaull, 2012; Taylor, 2008) in which the freedom fighter, Nelson Mandela, became the first black South African president. In spite of the democratic elections in 1994 and the African National Congress being in power for nearly eighteen years, the great majority of schools and learners who were neglected prior to 1994 due to apartheid policies are still being neglected, as their schools remain under-resourced. This becomes evident from protests, conflicts and strikes between unions such as SADTU and government (De Wet, 2013), as there seems to be to what Mahlangu and Pitsoe (2011) refer to as being a power struggle between the teacher unions and the South African government. Further evidence of this 'struggle' is found in news headlines relating to teacher salary demands (John, 2013), work conditions and differences on opinions of teaching being an essential service (De Wet, 2013), infra-structure and basic resources such as textbooks that are not delivered on time or not at all (Evans, 2013).

It appears that it is not always easy to categorise conflict, as it is a complex process that covers a vast field (Van Tonder, Havenga \& Visagie, 2008). However, Rahim (2011), Lewicki, Saunders and Barry (2011) and Speakman and Ryals (2010) suggest that one way of categorising conflict is by means of a four level personal-group typology namely, intrapersonal conflict, interpersonal conflict, intragroup conflict and intergroup conflict. For the purpose of this paper, the focus of this qualitative case study which forms part of a larger study (Cain, 2013), is on interpersonal conflict among primary school teachers from three previously disadvantaged schools that reside in close proximity in the Northern Areas of Port Elizabeth in the Eastern Cape Province in South Africa. These schools are being classified as being disadvantaged due to apartheid education and financing policies. The rationale for this study is to inform the participating teachers, the Port Elizabeth Education District Office, as well as the Provincial Eastern Cape Department of Education on what the participating teachers perceive as the consequences or results of conflict among educators at the residing schools, with a view to make educators and departmental officials aware of how conflict among educators is perceived, to influence the school and fellow educators. Although criticism has been lodged against case studies as one cannot generalise from it (Yin, 2009), yet, Stake (1995) argues that readers are in fact making generalisations from the findings to their contexts and hence are in a position to ascertain how plausible the findings are.

\section{Theoretical Perspectives on Conflict}

Conflict is not something that appears and then disappears and passes, rather it is an organic process-driven phenomenon that proceeds through several phases and reach various levels (Galtung, 2000). Ting-Toomey (1994, p. 360) states that "conflict ... is defined as the perceived and/or actual incompatibility of values, expectations, processes, or outcomes between 
two or more parties over substantive and/or relational issues." The three aspects that are clear here are that values, expectations, processes or outcomes regarding issues or goals seem to be causes of conflict. This seems to be in line with Galtung (2000) who posits that conflict arises as a consequence of incompatible goals. Galtung's (2000) ABC conflict framework postulates that attitude, behaviour and contradictions results in conflict. This is based on the premise that people have certain goals, needs or interests. When these goals, needs or interests are threatened, a contradiction emerges (Galtung, 2000). Lederach (2003) refers to conflict as a process that has an episode, similar to Galtung's (2000) contradiction, an epicentre and history. This implies that conflict results not necessarily as the result of one episode or contradiction that occurred once, but that history, i.e. previous events prior to the conflict episode have an influence on the emergence of conflict.

Looking at the ABC framework of Galtung (2000), this framework implies that when a goal that refers for example to an interest or need has not been realised, then this could result in an inward negative attitude as a result of frustration or an outward behaviour of verbal abuse or violence or even physical abuse-violence. Galtung (2000) argues that the manifestation of conflict is not always rational; in fact it could result in not only hurting the other person(s) or party involved, but also in hurting oneself in revenge or defence mode; the original or initial root conflict cause(s) may even recede into the background and the focus shifting to destroy the other party at all cost. This implies then that a cause(s) of conflict could become a 'living destroyer', but also holds positive possibilities for opening up communication, cooperation and resolution.

With reference to needs, Galtung (2000) refers to these needs as survival as individual or as the collective, well-being of the individual or group, identity and freedom. Rosenberg (2003) refers to needs as being physical survival, autonomy, self-expression, spiritual energy, nurturance, integrity, celebration of life, mental and interdependence; aspects that refer to human needs theory. Another aspect to take into consideration is that the focus of dealing with a conflict should be to arrive at creative outcomes instead of conflict becoming a destroyer (Galton, 2000). Recently, Bradshaw (2008) has extended the categorised causes of conflict of Moore (2003) as he has added the needs-based dimension. Hence, the current causes or bases of conflict are determined as relationships, values, data, structural aspects, interests and needs (Bradshaw, 2008). At the same time, it is important to note that when dealing with conflict, the outcomes of the conflict management approach could be win-lose, lose-win, lose-lose or winwin (Galton, 2000; Hitt, Miller \& Colella, 2006; Schermerhorn, Hunt \& Osborn 2000) while Hitt et al. (2006) add the possibilities of win-part, lose-part at the same time. This could result in that one person or party prevails and the other loses, withdrawal, avoidance, domination, compromise or even transcendence - achieving more than one has bargained for (Aquinas, 2006; Galton, 2000; Thomas, 1976).

\section{Conflict Theories}

In addition to Galtung's (2000) proposed ABC conflict framework above, several conflict theories have been proposed regarding the nature of conflict. It is important to take cognisance of McCorkle and Reese (2010) conceptual explanation of what a theory is, as they suggest that theories are tentative or provisional explanations, accounts or descriptions from observed or experiential actions or behaviours, or as Abigail and Cahn (2011, p. 211) state, "explaining how something works, ”suggesting 'trying' to explain. Abigail and Cahn (2011) provide an overview of conflict theories and have categorised it into three groups, each with subsequent sub-groups. These groups are intrapersonal conflict theories, relationship theories and structural theory. The first group is intrapersonal theory and is sub-divided into psychodynamic attribution and uncertainty theories. The second group is relationship theory which is sub-divided into social 
Gerard CAIN, André du PLESSIS. Teachers' Perceptions of the Consequences of Interpersonal Conflict: A Case Study in Three Primary Schools

OF MANAGEMENT IN THE $21^{\text {st }}$ CENTURY Volume 8, 2013

28

exchange, systems and transformational theories. The third group is structural conflict theory (Abigail \& Cahn, 2011).

Intrapersonal theories as a first grouping, refer to how individuals respond or act when conflict emerge and when they have to face it, the response being based on moods, attitudes, perceptions and mind-sets (Abigail \& Cahn, 2011). Psychodynamic theory as a sub-set, links to the Freudian perspective, referring to the role that the sub-conscious plays (Lulofs \& Cahn, 2000; Collins, 2005) or as Davies (2004) suggests; that a person's inner states, selves and minds influences behaviour or action, implying that behaviour can be eternalised or internalised, observable to other or non-observable. Attribution theory on the other hand, focuses on how individuals perceive another individual(s) involvement in the conflict, hence resulting in blaming as he/she attributes the conflict on certain perceptual inferences. Uncertainty theory refers to lack of information and misunderstanding (Abigail \& Cahn, 2011), probably as a result of miss-communication, no-communication, disinformation and different perceptions (Moore, 2003), similar to what Bradshaw (2008) refers to as data related conflict.

Relationships theories as a second grouping refer to our interdependence and the nature of our relationships with one another (Abigail \& Cahn, 2011; Lulofs \& Cahn, 2000). Social exchange theory and equity theory refers to individuals promoting their own self-interests through their actions (Davis, 2004), hence maximizing rewards for themselves (Abigail \& Cahn, 2011). An individual's action is thus a reaction as a result of another individual(s) action, the level being regulated to what extent objectives are compromised and to what extent the individuals involved in the conflict are beneficial while minimizing the cost (Abigail \& Cahn, 2011), not necessarily just in monetary terms. Equity theory has its roots in social exchange theory, but with a slight variation, as it hold that interaction and exchanges among individuals should be fair and just, hence balanced or equitable (Collins, 2005). Systems theory as a sub-set relates to the organic and living dimension of conflict, an aspect to which Galtung (2000) refers to. Within a system there are roles, processes, and patterns, hence it is important to ascertain which aspects are responsible for triggering the conflict and the changes it brings about within the system (Collins, 2005). Hence, within a system, it can thus be argued that the different elements within a system, e.g. roles, relationships, processes and patterns are affected by the events and these events again effect or have an influence on other events within the system. Transformation theory as conflict theory posits that conflict is a developmental tool that has the potential to develop relationships, the organisation and society as a result of contradictions between how things are at the moment and the perception of how it actually should be in reality (Collins, 2005), suggesting that conflict has a functional or positive outcome (Davies, 2004), hence double loop learning instead of single loop learning in order to improve relationships. Single-loop learning implies that the conflict is examined with a view to diagnose the problems without changing the existing policies, goals and assumptions (Rahim, 2002) whereas doubleloop learning refers to transcending the existing paradigm or mind-set, hence leading to changes in existing behavioural and cognition (Rahim, 2002).

Structural theory as a third grouping denotes that power, trust and uncertainty are important factors in order to develop deep cognition and comprehension of how these elements interplay within a current structure (Lulofs \& Cahn, 2000). It therefore questions who has the power, how much power, what interests are at stake, etc. (Lulofs \& Cahn, 2000).

\section{Categorising the Consequences of Conflict}

The focus of this paper is on the consequences of conflict. In his seminal works on conflict, Pondy (1967) states that conflict has not only negative outcomes, but also offers positive possibilities, or in his own words, "Conflict is not necessarily bad or good, but must be evaluated in terms of its individual and organizational functions and dysfunctions" (Pondy, 
1967, p. 319). Hence, Pondy $(1967,1969)$ has alluded to the functional and dysfunctional outcomes of conflict already. Buelens, Van den Broeck, Vanderheyden, Kreitner and Kinicki (2005), Cowan (2003), Mullins (1999) and Rahim (2011) also refer to the dysfunctional and functional outcomes of conflict.

Dysfunctional conflict, also termed destructive conflict (Parker \& Stone, 2003; Plocharczyk, 2007) are disruptive or distributive (Wood, Chapman, Fromholtz, Morrison, Wallace, Zeffane, Schermerhorn, Hunt \& Osborn, 2004) as it could lead to the non-realising of an organisation's goals (Ivancevich, Konopaske \& Matteson, 2005), the break-down of relationships among colleagues and at the same time alienating individuals and leading to the forming of contesting groups; drawing on feelings or perceptions rather than on the real underlying aspects as causes (Nelson \& Quick, 2008; Robbins \& Judge, 2009). It appears that dysfunctional conflict could result in unhappiness, feelings of stress and being stretched or overworked that also result in less or poorer communication with colleagues, hence leading to distrust, doubt and negative personal relationships (Rahim, 2011); even influencing those who remain dedicated and loyal (Rahim, 2011; Scott, 2010) and hence affecting staff morale and health (Scott, 2010), or as De Dreu, Van Dierendonck and De Best-Waldhober (2003), the individual's well-being. Further possible outcomes could be anger, anxiety, distress, fear and aggression; thus impeding on self-development and even problem solving (Tillet \& French, 2006). The above could result in non-social behaviour such as being self-destructive, verbal and physical abuse, or violence resulting in further breakdown of cohesion (Tillet \& French, 2006), playing the blaming game, non-cooperation and even explosive behaviour (Cowan, 2003), absenteeism, high staff turn-over (Bipath, 2008) and even death (Haraway \& Haraway, 2005).

In contrast to dysfunctional conflict, which appears to suggest that conflict seems to have a negative connotation with negative outcomes, conflict also offers the potential for functional outcomes (Cowan, 2003; Mullins, 1999: Rahim, 2011). Hence, conflict can be functional when it is constructive (Buelens, Van den Broeck, Vanderheyden, Kreitner \& Kinicki, 2005; Deutsch, 1969; Zide; 2005) or integrative (Wood, 2003). The positive dimension of the functional extent of conflict is succinctly summarised by Rahim (20011, p. 7) when he states, "if a social system is to benefit from conflict, the negative effects of conflict must be reduced, and positive effects must be enhanced." Hence, Rahim (2011) suggests that conflict has the potential to have positive outcomes if the negative dimensions of it can be reduced within an organisation, thus implying that person(s) have to be made aware of the fact that there are positive aspects that could emerge as a result of conflict among individuals (Erickson \& Mc Knight, 2001). Conflict that emerges and the management thereof could lead to greater knowledge and skills of not only dealing with conflict, but also to increasing productivity and innovation (Bacal, 2004), the creation of better solutions to problems, the clarification and clearing-up of personal differences and perceptions, resolving outstanding dilemmas (Mullins, 1999; Cowan, 2003), improved teamwork, commitment and greater understanding of co-workers (Bipath, 2008) and hence achieving the goals of the organisation (Plocharczyk, 2007) resulting in positive change (Ivancevich et al., 2005).

\section{Methodology of Research}

In the following subsections, an overview is provided of the research design and methodology that underpinned the research. 
Gerard CAIN, André du PLESSIS. Teachers' Perceptions of the Consequences of Interpersonal Conflict: A Case Study in Three Primary Schools

$\begin{array}{r}\text { PROBLEMS } \\ \text { OF MANAGEMENT } \\ \text { IN THE 21 } 1^{\text {st }} \text { CENTURY } \\ \text { Volume 8, 2013 } \\ \hline 30\end{array}$

\section{General Background}

From presenting the conceptualisation of conflict, conflict theories and the outcomes of conflict above, it emerged that these authors have focused primarily on conflict within organisations in general and not specifically with schools in the education fraternity. However, it is argued that the school is also an organisation and hence it is important to ascertain what the perceived outcomes of conflicts are according to educators in order to establish whether these outcomes are similar, or not with non-educational organisations. As South Africa is a young democracy that struggles with tension and conflict in education due the legacy of apartheid policies, as well as being highly unionised, it is important to ascertain why it is important to deal with conflict, hence the focus of this paper being on the perceived possible consequences or results of conflict among educators.

\section{Interpretive Paradigm: Qualitative Case Study}

The interpretive paradigm has as its core how our social world is perceived and understood (Henn, Weinstein \& Foard, 2006), a social world that is a social construct (Denzin \& Lincoln, 2005) and hence there are thus multiple co-constructed subjective realities and not only one objective reality (Johnson \& Onwuegbuzie, 2004). As this study focused on how educators perceived what the consequences of conflict as a phenomenon are through the 'eyes and ears' of the educators, a qualitative interpretive approach seemed to providing the participants with a voice, that provide an opportunity for them to articulate their inner feelings, perspectives, experiences and perceptions, thus "to gather their stories" (Patton, 2002, p. 240). The qualitative dimension provides also an opportunity to explore how individuals make meaning of a social or human problem (Creswell, 2009), the problem in this study being the perceived consequences of conflict among educators. The case study approach affords the researcher with an opportunity to investigate "within its real-life context" (Yin, 2009, p. 18). As a case study, it was particularistic, descriptive and exploratory (Merriam, 2009). It was particularistic as the focus was on a particular group of primary school teachers that resides in schools within close proximity from one another. It was descriptive as several different qualitative data gathering was used. It was exploratory as there was a need to obtain the participants' deeper insights related to conflict (Merriam, 2009). The aim was not to generalise, but to portray a picture of what the consequences of the phenomenon is as perceived by them. Readers can thus determine whether the findings seem to be believable (Stake, 1995).

\section{Research Context and Sample}

The participants were recruited from three primary schools in the Northern Areas of Port Elizabeth in South Africa. A combination of purposive and convenience sampling was used. It was purposive as the purpose was to explore the participants' perceptions regarding the consequences of conflict in schools that are in close proximity within a similar social context. It was convenient, as the researcher resides in one of the schools and had good rapport with the other two schools. Participants were teachers, head of departments, deputy principals and principals. There were 24 participants in School 1, 18 in School 2 and 17 in School 3, hence 59 participants in total.

\section{Data Collection Tools}

Data collection consisted of an open-ended questionnaire, individual semi-structured interviews and focus-group interviews. The open-ended questionnaire was completed by forty three participants, four participants were interviewed by means of a semi-structured interview 
and four focus-group interviews that consisted of three participants each were also conducted. Small focus-groups, referred to as mini focus-groups by Denscombe (2007), were used for various reasons. The researcher was of the opinion that large groups of participants would present more challenges in organising suitable interviewing sessions and venues and that it could be more cumbersome to capably handle interaction between participants who tended to dominate conversations and those who felt more restrained to speak out (Denscombe, 2010). Further, small focus-groups were deemed more suitable, since bigger groups could make the transcribing of data more complex (Hartas, 2010; Denscombe, 2010).

The open-ended questionnaire contained questions such as e.g.'Explain what you understand by the term "conflict", , 'Please elaborate on how you perceive possible positive and/or negative consequences in regard to how conflict affects educators and the school' whereas sample interview related questions were 'What do you understand by the term conflict among educators at school?', 'What are the consequences /effects that conflict has on schools?', 'How does it influence educators?' and 'What impact does it have on educators /the school?'. Probing was also employed to further explore responses of participants during both interviews and focus-group interviews.

\section{Ethical Considerations}

Ethical clearance was applied for through the university's Ethics Clearance Committee. This entailed that the District Office, Department of Education as well as principals of the three schools had to provide consent. After ethical clearance was received, the teachers at each of the three schools were informed about the intention of the research by the researcher during a staff meeting. Participants could decide on a voluntary basis whether they wanted to participate or not. All open ended questionnaires were completed anonymously and the recording of the interviews (semi-structured and focus-groups) were safely stored. No names were indicated when the data was transcribed and reported, but a number has been assigned to each participant. Participants also signed a form of consent to indicate that the data could be used for research purposes.

\section{Data Analysis}

The data were analysed and coded by using the suggestions of Creswell (2009, pp. 184-186) and Marshall and Rossman (2006). The data was transcribed and then the reading proceeded resulting in reading the same transcription several times. While reading, codes in symbolic form were assigned to aspects that the data suggested (Creswell, 2009:187). Each code was written on a piece of paper and the symbol associated with it adjacent to it. After all the data were read, the codes were written down and grouped into similar categories by combining similar codes. The data were then presented as a category, with each category explained as a qualitative narrative (Creswell, 2009). Interpretation followed by linking the findings to the literature and from the researcher's interpretation based on the data (Creswell, 2009).

\section{Ensuring Credibility and Trustworthiness}

In order to ensure credibility and trustworthiness, several measures were taken. These include that the data are available to be explored in order to ascertain whether the data are accurately presented and reported, the data tools are available, comprehensive descriptions have been provided as evidence when the categories are reported and several data gathering tools were used for triangulation purposes in order that the different tools could affirm and 'speak' to one another (Ary, Jacobs, Razavieh \& Sorenson, 2009). 
Gerard CAIN, André du PLESSIS. Teachers' Perceptions of the Consequences of Interpersonal Conflict: A Case Study in Three Primary Schools

\author{
PROBLEMS \\ OF MANAGEMENT \\ IN THE $21^{\text {st }}$ CENTURY \\ Volume 8, 2013 \\ 32 Results of Research
}

The results of the findings are reported as two main categories, each with sub-categories. The two main categories are related to negative and positive outcomes or consequences of conflict.

Negative Consequences

It was highlighted in the introduction and theoretical perspectives section that people seem to perceive conflict as something negative. The negative consequences from the data are presented as sub-categories below as perceived by the participating educators.

\title{
Defiant Attitudes and Intolerance towards Management
}

Defiance and intolerance towards the management and principal in particular were perceived as negative consequences. This seemed to occur as a result of management and principals not taking the viewpoints of staff members into consideration or not valuing the staff's concerns about school matters, resulting in staff trying to get back at management. This became evident when a participant mentioned that as a result of management at school, one becomes "Slack in your work, trying to get back at management, you didn't listen to me, so I'll show you now" (Focus group D, School 3, Participant 1). This was supported by another participant who stated that a consequence of management's position towards staff, lead to staff members to think "... I'm not gonna [going] do anything else, except what I'm supposed to $d o$, and that is teaching. Cause I'm not going to ... my issue was not taken seriously, that conflict was not resolved ..." (Personal interview, School 1, Participant R). Another participant concurred when stating that the favouring of certain staff members lead to an attitude that staff will do whatever they felt were acceptable to them, "... if they (certain educators who are in favour with the principal) can do that without anybody saying anything, uhm, so I'm going to do whatever I please" (Personal interview, School 1, Participant I).

\section{Poor Cooperation and Teamwork}

Poor cooperation and lack of teamwork, a consequence which appears to be linking to defiance and intolerance, also became apparent as a negative consequence. Poor cooperation as a consequence was highlighted when a participant mentioned "... cause conflict causes people not to work well together" (Focus group A, School 2, Participant 1) and another one wrote that conflict "Can cause lack of cooperation and teamwork" (Questionnaire, School 3, Participant 10). The above was affirmed by several participants when they stated that conflict "could lead to colleagues not being willing to participate or share in projects or tasks given in their committees, etc." (Questionnaire, School 2, Participant 2) and "People tend not to cooperate any more in reaching the goals of the institution"(Questionnaire, School 1, Participant 2), for example as staff start to "Refuse to cooperate with duties" (Questionnaire, School 1, Participant 17). The consequence was that even staff development team building that was aimed to promote cohesion, was boycotted, "... then also that is why people were reluctant even to go on team buildings or end of terms [staff functions] - they just thought they'd stay away" (Focus group C, School 1, Participant 1).

\section{Poor Relationships}

Educators felt that conflict impacted negatively on relationships among staff members within the workplace, as it compromised trust and collegial relationships, "Conflict at school cancels out camaraderie" (Focus group A, School 2, Participant 1). This was supported as 
participants mentioned that conflict causes "... a breakdown in relationships, if things are not solved correctly ..." (Personal interview, School 3, Participant I) as it "Breaks positive relationships of educators" (Questionnaire, School 1, Participant 15) and hence impact on healthy working relations, "Conflict could affect the healthy working relationships at school" (Questionnaire, School 3, Participant 12).

\title{
Division of Unity through the Formation of Groups and Cliques
}

Participants were of the opinion that conflict caused the formation of opposing groups or cliques at school, hence sowing the seeds of division, aspects that can also be linked to resulting in poor relationships and poor communication and teamwork presented above. This became apparent when participants stated, It [conflict] tends to break the unity ..." (Personal interview, School 3, Participant $G$ ) and another one added that cliques are formed due to conflict when mentioning:

\begin{abstract}
"... in terms of cliques that are created sometimes at school because of conflicts. Now, you know, once you have that, those cliques, I'm telling you, they can really blow even small things out of proportion. We have some tiff [disagreement] or some misunderstanding, but because now these people here are my clique, then if then now everybody here must suddenly take sides with me and then we must ignore this one and you find that even a small thing was blown out of proportion and now while these people, because this people were backing me up, and actually fuelling this thing, you know. Even when you now feel that, ag, [oh] you know, what at the end of the day, this was nonsense. But now because you have the backing of this people you know, it makes a mountain out of a molehill", (Focus group C, School 1, Participant 3).
\end{abstract}

This was supported when another participant stated that conflict results in "Disunity ... Formation of groups at school [opposing camps]. Staff form cliques, e.g. pro-principal and anti-principal" (Questionnaire, School 3, Participant 2), hence alluding to cliques or groupings as having their own agendas, causing division or rifts and straining relationships, "People will also develop cliques, and this means that the relations will be strained. This usually results in division among the staff" (Questionnaire, School 1, Participant 4).

\section{Poor Morale, Motivation and Work Ethic}

Conflict was also perceived as having an influence on morale, motivation and work ethic, as it became apparent when it was stated that conflict resulted in "No morale, educators were just simply down and out at one stage, because the leadership did not really lead as he (the principal) was supposed to lead. So the morale was low, no cooperation was given; everybody just had his own way of doing things and thinking" (Focus group C, School 1, Participant 1). This also appears to be linking with cooperation and teamwork, as poor morale and nonmotivation could impact on it. Participants further emphasized the consequence of conflict as demotivation when stating “... if I'm passionate about something, but every time you have this conflict, you're not going to have like that enthusiasm and drive anymore" (Personal interview, School 3, Participant I). Concurring, another participant highlighted the impact of conflict as demotivator that impact on how one perceive work ethic, when stating:

“... because that's the way you get up in the morning. And then when you get to school, you get yourself there, let me just work so that the day can go past quick. Do my work, done, go home. Hometime, go home, you are pleased to go home, because now you're away from this school. Tomorrow morning, same thing” (Focus group B, School 2, Participant 3). 
Gerard CAIN, André du PLESSIS. Teachers' Perceptions of the Consequences of Interpersonal Conflict: A Case Study in Three Primary Schools

$\begin{array}{r}\text { PROBLEMS } \\ \text { OF MANAGEMENT } \\ \text { IN THE 21 } 1^{\text {st }} \text { CENTURY } \\ \text { Volume 8, 2013 } \\ \hline 34\end{array}$

\section{Poor Health Causing Stress and Absenteeism}

Participants were adamant that conflict among educators, including management and the principal; result in affecting one's well-being. The impact as consequence of conflict on educator's health were highlighted when an educator stated “... and it sometimes makes people unhealthy, it makes one unhealthy as well and I mean we have this, we have evidence of colleagues who are on sick leave, you know, ... long term incapacity due to conflict ..." (Focus group C, School 1, Participant 2), a consequence that was affirmed when another participant wrote that conflict "Influences the health of educators"(Questionnaire, School 1, Participant 18), "Conflict at your workplace affects your mental and physical health" (Focus group A, School 2, Participant 1)resulting in "Stress amongst teachers" (Questionnaire, School 2, Participant 1).

The stress that conflict caused also appears to result in short term and long term absenteeism, as some staff members have been booked of by doctors for stress relief. The long term implication was alluded to when an educator said, "Stress relief, [be]cause you know, one of our colleagues is also on stress relief, because of conflict ..." (Personal interview, School 1, Participant R). Short term absenteeism as consequence was implicated when a participant wrote that "Teachers want to spite one another by staying at home" (Questionnaire, School 1, Participant 10). Absenteeism was further emphasised when a participant said:

"And the biggest problem that usually emanates from conflict situations is then you stay away from school and just don't feel like coming, because there's no drive. If you know that I'm going to be looking at participant 1 every day and I probably unfortunately have to be working close to her you know, with him and I do not now have a good working relationship, I would rather just stay away from him so it results therefore in absenteeism ..." (Focus group C, School 1, Participant 3).

\section{Compromising Teaching and Learners'Learning}

The participants were in agreement that the effect that conflict had at school, negatively impacted on the teaching and learning of their learners. This was highlighted by several participants when they stated:

"... they (the educators) lose their interest and their enthusiasm. You can actually see it in the way they carry themselves ... (conflict) impact on the whole functioning of the organisation and it also impacts on the children. Cause the children are not getting the best" (Personal interview, School 3, Participant G).

Another participant concurred that the learners were paying the price for conflict among educators, as it impacted on teacher performance. This became apparent when a participant wrote that conflict resulted that an "Educator could not perform her/his best in the class, because he or she is upset" (Questionnaire, School 1, Participant 6) and another participant added that the conflict among educators cannot be hidden and impact directly on the learners themselves:

“... because the learners knows about this conflict. They know this one and that one is not greeting or not speaking to one another or whatever and, and, this, uh, it's not a good thing for the learners and sometimes they want to go to another educator to ask something or to tell something, but then they, they keep it back ... But now because she knows he [learner] or she [learner] picked up this vibe between the educators, they don't feel free to go and ask teacher can you help me with, with this thing" (Focus group B, School 2, Participant 2). 
This was affirmed when another participant concurred:

"Conflict as we said is know that the school will suffer, cause that certain educators that is or well that's in that conflict, won't give their 100\%. Cause maybe some ... or they have an issue and it was not resolved eagerly, easily or, err, properly. You say no, the school doesn't take my feelings in consideration, so I'm not gonna give $100 \%$ to the learners ..." (Personal interview, School 1, Participant R).

The above clearly suggests that the consequences of conflict impacts on a wide range, often to the detriment of the learners, learners who are paying the price for something that they are not part of.

\section{Positive Consequences}

From the theoretical perspective section, it became evident that conflict does not always have negative consequences. The participants' perceptions regarding the possible positive consequences of conflict among educators are presented below.

\section{Improved Relationships}

A positive consequence of conflict that was identified was the fact that it could assist with cultivating improved relationships among educators at their workplace, an aspect that was highlighted by several participants when they stated that when conflict is dealt with in an amicable manner, it could restore and improve relationships as "... when two parties were involved and differences were thrashed out, a better working relationship develops ..." (Questionnaire, School 1, Participant 1). This was affirmed when participants mentioned, “... conflict isn't necessarily ... not a bad thing. It has to be there, because it, uhm ... it builds up stronger relationships with each other ..." (Personal interview, School 3, Participant I) and "... whenever relationships have been restored and people tend to work very good together the, the relationships are better" (Personal interview, School 1, Participant I). The above was also pointed out by a participant, who stated that positive relationships appears to emerge when conflict between individuals or among different parties is resolved in such a manner that there is a win-win outcome, "... I can see there's positive human relationships" (Personal interview, School 1, Participant R).

\section{Greater Understanding, Improved Attitudes and Positive Change}

Participants indicated not only that relationships have the potential to improve as a consequence through amicably dealing with conflict, but that understanding between individuals could also improve if the concerns or issues that individuals have are dealt with professionally. This was implied when participants mentioned that an outcome of dealing with conflict could be "Better understanding amongst colleagues" (Questionnaire, School 1, Participant 18), "It can bring about a better understanding, as parties realise their faults ..." (Questionnaire, School 2, Participant 7).

At the same time, a positive consequence could be that one becomes aware why a person acted in a certain way when one has dealt with the conflict, "... you now know why that person act like that and now you change your whole attitude towards that person ..." (Personal interview, School 1, Participant R) as "you clearly understand that person better now" (Personal interview, School 1, Participant R). Dealing with conflict hence also opens the way for not only understanding what has happened from another person's perspective, but also for realising that conflict is not necessarily personal, but an issue that is at hand as "... through that conflict, I've become more aware ... and not just looking at issues from my point of view" (Personal interview, School 3, Participant G) and fellow educators could: 
Gerard CAIN, André du PLESSIS. Teachers' Perceptions of the Consequences of Interpersonal Conflict: A Case Study in Three Primary Schools

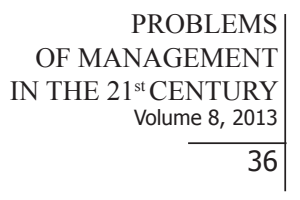

"... start to realise and things come up, it is not the person being attacked, cause that is number one thing, it is going to be the issue at hand. If you work constantly through conflict you'll notice, you'll discover that the resolution would be, it is not the people involved, it's the situation that the person find himself" (Focus group D, School 3, Participant 1).

This improved understanding could lead to positive change,"changes which benefit the school or other colleagues ..." (Questionnaire, School 1, Participant 11), hence assisting with the smooth running of the school, "At the end of the day, they agree about the smooth running of the school - they then push their differences aside and work towards one goal ..." (Questionnaire, School 2, Participant 1).

\title{
Personal Growth
}

Greater understanding, could also link to personal growth. One aspect related to personal growth seems that dealing with conflict and being exposed to it in the workplace affords opportunities to become a stronger person:

\begin{abstract}
“Well it's made me a stronger person. It's definitely made me a stronger person. I've learnt to stand on my feet, speak up for myself, not wait for my peers, I mean my colleagues, to do certain things for me, and, uh, follow my own mind. Not follow, uh, things that my colleagues have, ideas that they have and, and just follow them, you know. If I don't agree with something, I don't agree with something. So in other words, to put it in a nutshell, it's made me a stronger person" (Focus group B, School 2, Participant 1).
\end{abstract}

Another dimension is that it could result in personal reflection as personal growth, seeing what has occurred from different perspectives "... because if I sit back and reflect, know that one was right, and we should be big enough to say, OK, it was my fault or, and, and I, that problem won't arise again, because I am aware of what I've been doing, you know"(Focus group D, School 3, Participant 1).

\section{Discussion}

From the findings it is evident that conflict has not only negative or dysfunctional consequences, but also positive or functional ones concurring with the categorisation of Buelens et al. (2005), Cowan (2003) and Rahim (2011). However, from the data, it seems that the majority of consequences that were indicated by the participants were on the dysfunctional plane. Hence, overall, it appears that the consequences of conflict seemed to be suggesting that conflict is perceived as a negative phenomenon (Guttman, 2009; Pondy, 1967; Rahim, 2011; Samantara, 2004; Stanley \& Algert, 2007).

The findings suggest that conflict resulted in defiant attitudes or intolerance towards management, highlighting the fact that conflict has the capability to cause highly emotional sentiments and feelings (Tillet \& French, 2006), resulting in people opposing one another (Nelson \& Quick, 2008) that could even lead to negative behaviour and outrage (Tillet \& French, 2006). In addition, the perception of poor cooperation and teamwork due to conflict seems to by highlighting the fact that conflict can also cause division, an aspect that links to the defiant attitudinal dimension of conflict (Nelson\& Quick, 2008) and also triggers performance and cooperation in the workplace (Bipath, 2008; Rahim, 2011), an outcome that could also possibly have a negative effect on teaching and learning within the school context.

However, this is not where it ends, as ultimately conflict seems to impact on relationships among people within the school as organisation and impact negatively on unity (Kohlrieser, 2006; Rahim, 2011; Tillet \& French, 2006). Due to poor relationships, it appears from the data that conflict could lead to disunity and the formation of opposing groupings or camps, thus negatively impacting on how people interact and at the same time negatively affect 
cohesiveness (Tillet \& French, 2006) and result in doubt and distrust (Rahim, 2011). In addition, the consequences of conflict could also contribute to poor morale, motivation and work ethic, as

suggested by the data (Scott, 2010). The data highlights that eventually conflict impacts on the well-being of a person(s), resulting in poor health and stress (Haraway \& Haraway, 2005; Scott, 2010) which lead to absenteeism (Bipath, 2008; Haraway \& Haraway, 2005). Notwithstanding the above, whether educators are at the workplace and experience conflict in a negative light or whether they are absent, it becomes clear that it ultimately also negatively impacts the learners, as the stress and absenteeism takes its toll when learners are left without an educator in the classroom.

These negative consequences discussed above, seem to affirm several conflict theories. The findings above, with reference to the psychodynamic theory, appears to suggest that people's inner states, sub-conscious - our mind - influences our mood, behaviour, actions, perceptions and attitudes (Abigail \& Cahn, 2011; Lulofs \& Cahn, 2000). On the other hand, the perceived blame of other individuals, whether they are on the same horizontal level or in a leadership position, suggests that this can be ascribed to the attribution theory. The blame for conflict thus result due to the perceived involvement of another individual(s) in behaviours or actions that are perceived to be causing conflict (Abigail \& Cahn, 2011), the so-called other party as the cause.

The findings pertaining to the negative consequences of conflict appears to also link with the human needs theory of Galtung (2000) and Rosenberg (2003), as the educators indicated that their individual well-being were at stake, hence there survival (Galtung, 2000; Rosenberg, 2003). As the educators indicated that their self-expression were not valued, this resulted in causing negative conflict as their self-expression (Rosenberg, 2003) were not recognised and furthermore they could thus not celebrate their educational life and as such it seems that the negative energy on various levels affected their well-being (Galtung, 2000; Rosenberg, 2003).

At the same time, the data also suggests that conflict could have positive or functional outcomes, especially if it is dealt with in an amicable mode, for example leading towards improving relationships, relationships that has been skewered due to conflict among educators and hence result in being drawn closer to one another (Anstey, 2006; Hitt et al., 2006). Linked to improved relationships, is that when conflict is dealt with in a manner that is acceptable to those involved in a way that their needs have been addressed (Galtung, 2000; Rosenberg, 2003), that the interactions and discussions that were part of solving the conflict, could result that the parties involved are assisted to understand the positions of one another and why they have acted or behaved in a certain ways(s). Thus, the greater understanding of each other's position by dealing with it, could also lead to improving the attitudes (Nelson \& Quick, 2008) not only of those directly involved in the conflict, but also those who have been indirectly involved. This then could lead to positive changes and could serve to position teaching and learning of the learners at the centre of the teaching act. The management's actions in dealing with conflict is thus important, since if the parties involved perceive it (management's actions) in a positive light, then this could also result in rejuvenation, cooperation and dedication - assisting those in leadership positions as well as individuals to obtain deeper insight into the thinking and perceptions of their colleagues (Bipath, 2008). Through understanding one another as a result of confronting conflict in a positive manner, this could also enable personal growth among those involved, as one can enhance the inner self when dealing with conflict and settling disputes or differences (Deutsch, 1969).

The positive consequences of conflict appears to suggest that the psychodynamic state, or more explicitly, the intrapersonal dimension, can be changed as a positive outcome could lead to a positive inner state, mood and mind; suggesting that current negative behaviours and actions can be changed. Furthermore, the transformational possibilities offered through transformational theory, could lead to changing how things currently are, to how it is perceived 
Gerard CAIN, André du PLESSIS. Teachers' Perceptions of the Consequences of Interpersonal Conflict: A Case Study in Three Primary Schools

OF MANAGEMENT

IN THE $21^{\text {st }}$ CENTURY Volume 8, 2013

or believed, to how it actually should be (Collins, 2004). Thus, resulting in double-loop learning, i.e. changing those aspects such as policies, goals and assumptions that hampers change; resulting in a positive and change in mind-set (Rahim, 2002).

\section{Conclusions}

It becomes clear from this case study, that conflict is part of our social fabric and our daily lives. It is a force that has to be reckoned with. However, its consequences are not just negative. This became evident from the data as participants highlighted the positive consequences of a phenomenon that seems to be perceived as predominantly negative. The findings of this study affirmed that schools as organisations and their staff are not immune to conflict, as the negative consequences such as defiant attitudes, intolerance, poor cooperation and teamwork, poor relationships, division of unity, poor morale and work ethic, negative impact on wellness, absenteeism and adverse effects on learners' learning have been affirmed in other studies. However, these studies were not conducted in schools.

There are various implications for the management of schools. Management needs to accept that conflict is an integral facet of humanity and that they (management) has to gain a deeper understanding of all the numerous aspects of conflict in order to manage conflict in a more apposite way. Further, management needs to engage with other role-players from especially district education departments and Non Governmental Organisations regarding conflict-related development programmes that could assist in conflict management and resolution. Also, it is imperative that management gains access to professional development courses and training that could improve their (management's) knowledge of conflict in order for them to be better prepared in dealing with all the aspects of conflict.

It appears that the international consequences of conflict are also consequences that are evident in the South African school context. Despite of all the doom and gloom, it seems that there were also positive perceived consequences when conflict was perceived as having been dealt with in an amicable way. This became evident as participants highlighted that positive perceived consequences when dealing with conflict, were improved relationships among staff, greater understanding, improved attitudes, positive change and even personal growth. These findings concur with the results of international studies as indicated when the literature was infused in the discussion section.

The findings of this study thus highlights the possibility of viewing conflict as conflict being a "productive force" (Bacal, 2004, p. 21), a force that could not only assist colleagues to increase their knowledge and skills, but also a force that could lead to greater understanding, relationships and the functioning of the school. At the same time it is important to acknowledge that educators should never underestimate the harm that conflict could cause. Hence, conflict as contradiction to our current values, expectations and goals; whatever these might be, has to be dealt with as dealing with it could result in changes in attitudes and behaviours (Galtung, 2000). Therefore it is important to deal with conflict in an amicable way in order that its positive possibilities could be realised, possibilities that could lead to transformation of the current issues or aspects that seem to be the thorns in the flesh of educators and their working contexts as a system.

\section{Note}

Gerard Cain is a student at the NMMU, who has completed his Master's in Education related to conflict among educators. He was awarded the degree Cum Laude for his dissertation. This paper is based on a section from his dissertation. 
Gerard CAIN, André du PLESSIS. Teachers' Perceptions of the Consequences of Interpersonal Conflict: A Case Study in Three Primary Schools

\section{Acknowledgements}

Thanks to The Africa America Institute which granted me a scholarship via the Ford Foundation International Fellowships Program in completing my Masters' Degree.

\section{References}

Abigail, R. A. \& Cahn, D. D. (2011). Managing Conflict through Communication. Boston: Allyn \& Bacon.

Ahuja, P. (2006). How to Resolve Conflicts. New Delhi : Sterling.

Anstey, M. (2006). Managing Change Negotiating Conflict. New Delhi: Excel.

Aquinas, P. (2006). Organizational Behaviour: Concepts, Applications and Challenges. New Delhi: Excel Books.

Ary, D., Jacobs, L. C., Razavieh, A., \& Sorensen, C. (2009). Introduction to Research in Education (8th ed.). Belmont: Wadsworth Cengage Learning.

Bacal, R., 2004. Organizational Conflict - The Good, the Bad, and the Ugly. Journal for Quality \& Participation, 27 (2), 21-22.

Bipath, K. (2008). People in Action. In J. N. Heystek, J. Heystek, R. Niemann, J. Van Rooyen, J. Mosoge, \& K. Bipath (Eds.), People Leadership in Education (pp. 55-93). Sandton: Heinemann.

Bradshaw, G. (2008). Conflict Management for South African Students: Theory and Application. Cape Town: New Voices Publishing.

Buelens, M., Van den Broeck, H., Vanderheyden, K., Kreitner, R., \& Kinicki, A. (2005). Organizational Behaviour. London: McGraw Hill.

Cain, G. C. (2013). Educators' perceptions of conflict at three Northern Area Schools in Port Elizabeth: A Case Study. Unpublished MEd Thesis, Nelson Mandela Metropolitan University: South Africa.

Collins, S. D. (2005). Managing Conflict and Workplace Relationships. Managerial Communications (2nd Ed.) with O'Rourke, J. S. as Editor of the Series. (J. S. O’Rourke, Ed.) Ohio: Thomson South-Western.

Cowan, D. (2003). Taking Charge of Organizational Conflict. California: Personhood Press.

Creswell, J. W. (2009). Research design. Qualitative, quantitative, and mixed methods approaches. (3rd Ed.). Los Angeles, CA: Sage.

Davies, L. (2004). Education and Conflict. London: RoutledgeFalmer.

De Dreu, C. K. W., Van Dierendonck, D., \& De Best-Waldhober, M. (2003). Conflict at Work and Individual Well-Being. In M. W. Schabracq, M. Schabracq, J. Winnbust, \& C. \& Cooper (Eds.), The Handbook of Work \& Health Psychology (pp. 495-515). West Sussex: John Wiley \& Sons, Ltd.

Denscombe, M. (2007). The Good Research Guide for Small-Scale Social Research Projects (3rd Ed.). Berkshire: Open University Press, McGraw-Hill.

Denscombe, M. (2010). The Good Research Guide: For Small-Scale Research Projects (4th Ed.). Maidenhead: McGraw-Hill/Open University Press.

Denzin, N., \& Lincoln, Y. (2005). The Sage handbook of qualitative research (3rd Ed.). Thousand Oaks, CA.: Sage.

Deutsch, M. (1969). Conflicts: Productive and destructive. Journal of Social Issues, 25 (1), 7-42.

De Wet, P. (2013). ANC's push for teaching as an essential service augurs conflict. Mail and Guardian, 06 February 2013.

Du Plessis, A., Eloff, I., \& Bouwer, C. (2002). Using interpersonal skills to enhance learning. In L. Calitz, O. L. Fuglestad, L. Calitz, O. L. Fuglestad, \& S. Lillejord (Eds.), Leadership in EducationProviding learning cultures (pp. 217-235). Sandown: Heinemann.

Erickson, S. K., \& Mc Knight, M. S. (2001). The Practitioner's Guide to Mediation. A Client-Centred Approach. New York: John Wiley \& Sons, Inc.

Evans, S. (2013). Textbook saga smacks of meddling. Mail and Guardian, 31 May 2013.

Galtung, J. (2000).Conflict Transformation by Peaceful Means (the Transcend Method). New York: United Nations Disaster Management Program.

Guttman, H. (2009). Conflict Management as a Core Competency for HR Professionals. People Strategy, $32(1), 32-39$. 
Gerard CAIN, André du PLESSIS. Teachers' Perceptions of the Consequences of Interpersonal Conflict: A Case Study in Three Primary Schools

PROBLEMS
OF MANAGEMENT
N THE $21^{\text {st }}$ CENTURY IN THE $21^{\text {st }}$ CENTURY
Volume 8,2013

Haraway, D. L., \& Haraway, W. L. (2005). Analysis of the Effect of Conflict-Management and Resolution Training on Employee Stress at a Healthcare Organization. Taylor \& Francis Online: Hospital Topics, 83 (4), 11-17.

Hartas, D. (2010). Quantitative Research as a Method of Inquiry in Education. In D. Hartas, ed. Educational Research and Inquiry: Qualitative and Quantitative Approaches. London: Continuum. pp. 6581.

Hendel, T., Fish, M., \& Galon, V. (2005). Leadership Style and Choice of Strategy in Conflict Management Among Israeli Nurse Managers in General Hospitals. Journal of Nursing Management, 13 (2), $137-146$

Henn, M., Weinstein, M., \& Foard, N. (2006). A Short Introduction to Social Research. London: Sage.

Hitt, M. A., Miller, C. C., \& Colella, A. (2006). Organizational Behavior: A Strategic Approach. Hoboken: Wiley.

Ikeda, A. A., Veludo-de-Oliveira, T. M., \& Campomar, M. C. (2005). Organizational Conflicts Perceived by Marketing Executives. Electronic Journal of Business and Organization Studies, 10 (1), 2227.

Ivancevich, J. M., Konopaske, R., \& Matteson, M. T. (2005). Organizational Behavior and Management. Boston: McGraw-Hill

John, V. (2013). Teachers still waiting for their salaries. Mail and Guardian, 19 July 2013.

Johnson, R. B., \& Onwuegbuzie, A. J. (2004). Mixed Methods Research: A Research Paradigm Whose Time Has Come. Educational Researcher, 33 (7), 14-26.

Kohlrieser, G. (2006). Hostage at the Table. San Francisco: Wiley.

Lederach, J. P. (2003). The Little Book of Conflict Transformation. Good Books.

Lewicki, R., Saunders , D., \& Barry, B. (2011). Essentials of Negotiations. New York: Mc Graw HGill.

Lulofs, R. S., \& Cahn, D. D. (2000). Conflict: From Theory to Action (2nd Ed.). Boston: Allyn \& Bacon.

Mahlangu, V., \& Pitsoe, V. J. (2011). Power Struggle between Government and the Teacher Unions in South Africa. Journal of Emerging Trends in Educational Research and Policy Studies (JETERAPS), 2 (5), 365-371.

Marshall, C., \& Rossman, G. B. (2006). Designing Qualitative Research (4th Ed.). Thousand Oaks: Sage Publications.

McCorkle, S., \& Reese, M. J. (2010). Personal Conflict Management: Theory and Practice. Boise State University: Pearson.

Merriam, S. B. (2009). Qualitative Research: A Guide to Design and Implementation. San Francisco: Jossey-Bass.

Moore, C. (2003). The Mediation Process. San Francisco: Jossey Bass.

Mullins, L. (1999). Management and Organisational Behaviour. London: Financial Times Pitman Publishing.

Nelson, D., \& Quick, J. (2008). Understanding Organizational Behavior. Mason: Thomson.

Ngcobo, T. (2003). Conflict Management. In J. M. Lumby, J. M. Lumby, \& E. Kaaba (Eds.), Managing Human Resources in South African Schools (pp. 187-199). London: Commonwealth Secretariat.

Parker, C., \& Stone, B. (2003). Developing Management Skills for Leadership. London: Prentice Hall Financial Times.

Patton, M. Q. (2002). Qualitative Research and Evaluation Methods (3rd Ed.). Thousand Oaks: Sage.

Plocharczyk, L. (2007). On Organizational Conflict: Reaping the Benefits of Effective Conflict Management. Journal of Access Services, 4 (1-2), 85-120.

Pondy, L. R. (1967). Organizational Conflict: Concepts and Models. Administration Quarterly, 12 (2), 296-320

Pondy, L. R. (1969). Varieties of Organizational Conflict. Administrative Science Quarterly, 14 (4), 499 505.

Rahim, M. A. (2002). Toward a Theory of Managing Organizational Conflict. The International Journal of Conflict Management, 13 (2), 206-235.

Rahim, M. A. (2011). Managing Conflict in Organizations (4th Ed.). New Brunswick: Transaction Publishers.

Rosenberg, M. (2003). Nonviolent Communication. A Language of Life. California: Puddle Dancer Press. 
Gerard CAIN, André du PLESSIS. Teachers' Perceptions of the Consequences of Interpersonal Conflict: A Case Study in Three Primary Schools

Robbins, S. P., \& Judge, T. A. ( 2009). Organizational Behavior. New Jersey: Pearson Prentice Hall.

Rosenberg, M. (2003). Nonviolent Communication. A Language of Life. California: Puddle Dancer Press.

Samantara, R. (2004). Conflict Management Strategies and Organizational Effectiveness. Indian Journal of Industrial Relations, 39 (3), 298-323.

Schermerhorn, J. R., Hunt, J. G., \& Osborn, R. N. (2000). Organizational Behavior. New York: John Wiley \& Sons.

Scott, V. (2010). Conflict Resolution at Work for Dummies. New Jersey: Wiley.

Spaull, N. (2012). Poverty \& Privilege: Primary School Inequality in South Africa. Stellenbosch Economic Working Papers, 13/12. July 2012.

Speakman, J., \& Ryals, L. (2010). A Re-evaluation of Conflict Theory for the Management of Multiple, Simultaneous Conflict Episodes. International Journal of Conflict Management, 21 (2), 186201.

Stake, R. E. (1995). The Art of Case Study. Thousand Oaks: Sage.

Stanley, C., \& Algert, N. (2007). An Exploratory Study of the Conflict Management Styles of Department Heads in a Research University Setting. Innovative Higher Education, 32 (1), 49-65.

Taylor, N. (2008). What's wrong with South African schools? Presentation to the ConferenceWhat's Working in School Development. JET Education Services, 28-29 February 2008.

Taylor, N. (2007). Equity, efficiency the development of South African Schools. In Townsend, T. (Ed.), International handbook of school effectiveness and school improvement (pp. 523-540). Dordrecht: Springer.

Thomas, K. (1976). Conflict and Conflict Management. In M. D. Dinette, Ed. Handbook of Industrial and Organizational Psychology. Chicago: Rand McNally College Publishing Company. pp.889935.

Tillet, G., \& French, B. (2006). Resolving Conflict. Melbourne: Oxford University Press.

Ting-Toomey, S. (1994). "Manageging intercultural conflicts effectively." In L. Samovar \& R. Porter's Intercultural Communication: A reader. $7^{\text {th }}$ Ed., 360-372. Wadsworth, Belmont, CA

Van Tonder, C., Havenga, W., \& Visagie, J. (2008). The Causes of Conflict in Public and Private Sector Organizations in South Africa. Managing Global Transitions, 6 (4), 373-401.

Wood, J. (2003). Constructive Conflict in Discussions: Learning to Manage Disagreements Effectively. In J. Gordon, Pfeiffers Classic Activities for Managing Conflict at Work (pp. 67-72). San Francisco: John Wiley \& Sons.

Wood, J., Chapman, J., Fromholtz, M., Morrison, V., Wallace, J., Zeffane, M., Schermerhorn, J., Hunt, J., \& Osborn, R. (2004). Organisational Behaviour: A Global Perspective. Sydney: Wiley.

Yin, R. K. (2009). Case study research. Design and methods (4th Ed.). Los Angeles, CA: Sage.

Zide, G. (2005, October). Managing and Resolving Conflict in the Workplace. Management Today, $52-$ 55.

Advised by Vincentas Lamanauskas, University of Siauliai, Lithuania

Received: October 15, 2013

Accepted: November 17, 2013

\begin{tabular}{|ll|}
\hline Gerard Cain & $\begin{array}{l}\text { MEd cum laude, Teacher and Head of Department at a Primary School in Port } \\
\text { Elizabeth, South Africa. } \\
\text { E-mail: rcain@mweb.co.za }\end{array}$ \\
\hline $\begin{array}{l}\text { André du Plessis } \\
\text { (Corresponding Author) }\end{array}$ & $\begin{array}{l}\text { Ph.D., Senior Lecturer, Faculty of Education, Nelson Mandela Metropolitan Univer- } \\
\text { sity, PO Box 77000, Port Elizabeth, 6031, South Africa. } \\
\text { E-mail: andre.duplessis@nmmu.ac.za } \\
\text { Website: http://www.nmmu.ac.za/helpingteachers/individualprojectduplessis/index. } \\
\text { htm }\end{array}$ \\
\hline
\end{tabular}

